\title{
TRANSFORMASI NEGASI DIMENSI KEHAMBAAN PENGAMAL SHOLAWAT WAHIDIYAH DAN IMPLEMENTASINYA PADA LEMBAGA PENDIDIKAN FORMAL
}

\author{
Zumrotul Mukaffa \\ Universitas Islam Negeri Sunan Ampel Surabaya, Indonesia \\ E-mail: zumrotul_mukaffa07@yahoo.com
}

\begin{abstract}
This article examines the disappearance of the dimension of servitude among the members Sholawat Wahidiyah. The results of this study indicate that the variety of human normative responsibilities as a manifestation of the dimension of servitude to God (takälif) is valid for negation without reducing the degree of obedience. The validity of the negation occurs when the members are on their spiritual journey in the phase of fän al-majdhüb. The provisions of the validity of the negation depend on the time of the phase of the journey. Practitioners who have arrived at this degree are totally free from all their responsibilities theo-centrically, as servants who are bound by devotion to their Lord. The validity of the negation refers to the mystical perspective and experience of prominent sufis, such as Ibn 'Arabī and 'Abd al-Wahāb al-Sha'rānī. As an inseparable part of mujāhadah, the doctrine of fâni al-majdhüb is also transformed into a formal education environment managed by the practicioners Sholawat Wahidiyah. Thus, this doctrine is not only projected for members who have been mature in terms of age and spiritual journey, but also for students at the elementary and secondary levels of education.
\end{abstract}

Keywords: Sholawat Wahidiyah; fānì al-majdhüb; dimension of servitude.

\section{Pendahuluan}

Hilangnya dimensi kehambaan dalam diri manusia sebagai salah satu doktrin yang mendapat pengakuan khusus di kalangan pengamal Sholawat Wahidiyah (selanjutnya disingkat SW). Dimensi kehambaan menunjuk pada pengakuan dan pengukuhan tentang posisi manusia secara teosentris adalah hamba Tuhan ('abd Allab). Perspektif 
teosentris ini berkonsekuensi pada posisi manusia dalam ruang antroposentris, bahwa keseluruhan hidup dan kehidupannya sematamata hadir dan dihadirkan untuk mengabdi atau beribadah kepada Tuhannya. Dalam bahasa lain dikatakan, setiap manusia memiliki ragam tanggung jawab normatif (takälif) untuk selalu merepresentasikan sebagai hamba Tuhan yang taat, sungguh, dan konsisten. Ketidaktaatan terhadap tanggung jawab akan menempatkan manusia menegasikan dimensi kehambaan yang seharusnya selalu melekat dalam dirinya. Dalam peristiwa tertentu, negasi terhadap dimensi kehambaan justru dipahami Wahidiyah diyakini sebagai bagian dari bentuk ketaatan.

Wahidiyah merupakan salah satu organisasi sufi yang unik, fenomenal, dan kontroversial. Organisasi ini didirikan oleh ulama lokal dari Kedung Lo Kediri yang bernama KH Abdul Madjid Ma'ruf yang berusia masih sangat muda, jika dibanding dengan ragam organisasi atau ordo sufi/tarekat sufi yang berkembang di tanah air. ${ }^{1}$ Keunikannya terletak pada pemertahanannya terhadap klaim para pengikutnya bahwa, Wahidiyah bukan tarekat dalam pengertian formal, melainkan organisasi yang menjadi wadah bagi komunitas Muslim untuk membingkai perjalanan sufistiknya dengan bertumpu pada pengamalan Sholawat Wahidiyah. Oleh karena bukan sebagai organisasi tarekat, maka kalangan internal ada yang menyebutnya sebagai gerakan tasawuf kultural. ${ }^{2}$ Pada saat yang sama, tujuan organisasi maupun proses perjalanan spiritual untuk mencapainya nyaris tidak ada bedanya dengan tarekat-tarekat yang ada.

Pada saat yang sama, Wahidiyah juga sangat fenomenal, jika dilihat dari perkembangannya. Saat ini, para pengamalnya tidak hanya terkonsentrasi di daerah-daerah Jawa Timur, seperti Kediri, Jombang,

${ }^{1}$ Kelahiran Wahidiyah bermula ketika Kiai Madjid sebagai pengarang mendapatkan petunjuk ghaib untuk pertama kali pada tahun 1959 untuk terlibat secara aktif dalam penyelesaian permasalahan sosial kemasyarakatan saat itu. Petunjuk yang sama kembali terulang di tahun 1963 sebanyak dua kali, sehingga ia kemudian memutuskan untuk menyusun Sholawat Wahidiyah dan mulai diperkenalkan kepada lingkungan terbatas. Pada tahun 1964, shalawat ini mulai dipublikasikan secara luas kepada masyarakat Muslim, terutama di daerah Kediri dan sekitarnya. Dengan demikian dapat dikatakan, Wahidiyah sebenarnya baru mulai berdiri dan mengalami perkembangan sejak tahun 1963. Arif Zamhari, Rituals of Islamic Spirituality: a Study of Majlis Dhikr Groups in East Java (Canberra: The Australian National University, 2000).

2 Sokhi Huda, Tasawuf Kultural: Fenomena Sholawat Wabidiyah (Yogyakarta: LKiS, 2008). 
dan sekitarnya. Sebagai organisasi sufi non-tarekat yang relatif masih muda usianya, Wahidiyah juga telah berkembang di daerah-daerah lain di Jawa, terutama Jawa Barat dan DKI Jakarta. Bahkan organisasi ini juga telah memiliki pengamal yang berasal dari luar Negeri. Banyak pengamal Wahidiyah yang berasal dari Timor Leste, Malaysia, Brunai Darussalam, Singapura, Australia, Hongkong, Jepang, Arab Saudi, Selandia Baru, Peru dan Amerika Serikat. ${ }^{3}$

Kehadirannya yang seringkali dipahami masyarakat lekat dengan kontroversi juga menjadi bagian tak perpisahkan dari Wahidiyah. Di beberapa daerah, masyarakat Muslim belum dapat sepenuhnya menerima organisasi sufi non-tarekat tersebut. Mereka melakukan penolakan dan bahkan disertai tindakan kekerasan terhadap para pengamalnya. Hal ini, misalnya, terjadi Tasikmalaya Jawa Barat pada tahun 2007. Dengan mendasarkan fatwa Majelis Ulama Indonesia (MUI) Tasikmalaya, Front Pembela Islam (FPI) melakukan tindakan anarkhis terhadap para tokoh, pengamal, dan segala bentuk aktivitas Wahidiyah. Penolakan juga terjadi di beberapa tempat lain, seperti Serang (Banten) dan Pamekasan (Jawa Timur) yang keduanya terjadi di tahun 2012. ${ }^{4}$

Wahidiyah dipahami sebagai organisasi sufi non-tarekat yang kontroversial jika ditilik pada varian doktrin sufistik yang dibawanya. Organisasi ini begitu lekat dengan doktrin-doktrin yang selama ini menjadi bagian dari tasawuf falsafi, seperti istighräq, fanā' fì al-dhät, alhaqiqah al-Muhammadiyah, dan seterusnya. Penjelasan lebih luas tentang doktrin-doktrin tersebut semakin menempatkan Wahidiyah dekat dengan dimensi tasawuf falsafi yang bercorak panteistik. Konsekuensi dari istighrāq, misalnya, menghadirkan pengakuan dari internal Wahidiyah tentang adanya gugurnya kewajiban (suqüt al-taklïf) bagi para pengamal yang telah sampai pada fase wusül kepada Allah.

Menarik dicermati bahwa ragam doktrin yang masih dianggap kontroversial tidak hanya ditransformasikan dan sekaligus diimplementasikan oleh pengamal SW yang sudah matang, baik secara

\footnotetext{
3 Arif Muzayin Shofwan, "Dakwah Sufistik KH. Abdoel Madjid Ma'roef Melalui Tarekat Wahidiyah", Jurnal Studi Masyarakat, Religi, dan Tradisi, Vol. 3, No. 1 (Juni 2017), 91-104.

4 Moh. Zahid, "Islam Wahidiyah, Ajaran dan Pengamalan Shalawât Wahidiyah dalam Mainstream Islam Masyarakat Madura", al-Ihkam: Jurnal Hukum dan Pranata Sosial, Vol. 7, No. 2 (Desember 2012), 383-400; Moch. Nur Ichwan, “The Local Politics of Orthodoxy: The Majelis Ulama Indonesia in the Post-New Order Banten”, Journal of Indonesian Islam, Vol. 6, No. 1 (Juni 2012), 165-194.
} 
usia maupun perjalanan sufistiknya. Lebih dari itu, doktrin ini juga ditransformasikan sekaligus diartikulasikan ke dalam bentuk aktivitas sufistik yang nyata di kalangan peserta didik jenjang pendidikan dasar dan menengah, tepatnya mereka yang sedang menempuh pembelajaran di SMP/MTs dan SMA/SMK/MA, bahkan perguruan tinggi. Transformasi dan artikulasi berlangsung melalui lembagalembaga pendidikan formal yang dikelola oleh elit pengamal SW.

Artikel ini menelusuri ragam doktrin Wahidiyah yang memberikan hak bagi setiap pengamal untuk tidak terkena kewajiban yang mengikat dalam kedudukannya hamba Tuhan. Penting dicatat di sini bahwa pengakuan suqüt al-taklif sama halnya dengan menegasikan dimensi kehambaan yang seharusnya melekat dalam diri setiap Muslim sepanjang hayat. Pengakuan manusia sebagai hamba memiliki dimensi yang sangat luas, dan terkait dengan ragam pengabdian mutlak hanya semata-mata kepada Tuhan. Pengabdian dimanifestasikan kepada ketaatan seorang Muslim untuk menyelaraskan keseluruhan sikap dan perilakunya dengan lima hukum normatif yang telah ditentukan Tuhan. Selain itu, artikel ini mengkaji tentang pola transformasi doktrin pengakuan suqüt al-taklîf di lembaga pendidikan jenjang dasar dan menengah yang dikelola oleh elit pengamal Wahidiyah.

\section{Dimensi Kehambaan dalam Bingkai Hukum Taklifi}

Dimensi kehambaan ('ubüdìyah) memiliki relasi yang sangat lekat dengan munculnya pembakuan (tadwin) hukum-hukum sharí'ah yang bersifat mengikat (al-ableam al-taklifizah) kepada seluruh umat Muslim. Kesepakatan atas hadirnya lima ketentuan hukum taklifi pada dasarnya untuk menjadi pedoman dan sekaligus rambu-rambu agar setiap Muslim tidak menegasikan dimensi kehambaan tersebut. Oleh karena itu, ketika hukum taklifi tidak lagi berfungsi sebagai panduan dalam perilaku sosial dan keagamaan seorang Muslim, maka ia dengan sendirinya telah melakukan negasi terhadap dimensi kehambaan.

Dalam kajian maqāsid al-sharíah ditegaskan, salah satu tujuan utama diturunkannya sharīah Islam adalah pemenuhan hak-hak Tuhan terhadap makhluknya (maqāsid al-khäliq min al-khalq). ${ }^{5}$ Seluruh umat manusia, termasuk umat Muslim wajib menjaga dan memenuhi hak Tuhan sebagai satu-satunya Dzat yang harus disembah dan tidak ada sekutu bagi-Nya. Beberapa ayat al-Qur'ān, seperti Q.S. al-Dhāriyāt

5 Yūsuf Hāmid al-'Ālim, al-Maqāsid al-Āmmah li al-Sharī'ah al-Islāmīyah (Riyad: Dār al'Ālamīyah li al-Kitāb al-Islāmī, 1994), 82. 
[51]: 56, Q.S. al-Naḥl [16]: 36, Q.S. al-Anbiyā' [21]: 25, dan Q.S. alZukhruf [43]: 45 dengan tegas menebut hak tersebut dan bersifat mengikat.

Ketika tujuan Pencipta kepada makhluk supaya mereka menyembah dan tidak menyekutukan-Nya dengan suatu apapun, maka sesungguhnya tujuan pasti akan kembali pada inti apa yang kehendaki oleh yang memiliki tujuan ('awdah thamrat al-maqsīd ila al$q \overline{a s i} i d)$. Oleh karena itu, ketika kita menghubungkannya dengan yang dikehendaki oleh pembuat sharīah (Shäri $\left.{ }^{\top}\right)$, maka tidak ada jalan lain yang dituju, kecuali mengetahui Allah, beribadah kepada-Nya dan bukan selain-Nya, (hanya) akan kembali kepada-Nya yang Maha Tinggi dan Maha Besar. Seluruh orientasi beban tanggung jawab yang harus disegerakan pelaksanaanya (sebagai konsekuensi pemenuban bak Allab) kembali kepada manusia yang menerima beban tanggung jawab (mukallaf). Hal ini sudah cukup jelas dan tidak perlu diragukan, karena sesungguhnya Allah Maha Kaya dari seluruh alam, sebagaimana ditegaskan dalam ayat: Wabai manusia, engkaulah yang membutubkan kepada Allah, dan Allab Dia-lah Maha Kaya lagi Maha Terpuji (Q.S. Fātir [35]: 15)"'.

Keharusan umat Muslim untuk mengabdi sebagai hamba di hadapan Tuhannya, bukan berarti Tuhan membutuhkannya. Aksentuasi segala bentuk tanggung jawab yang mengikat dalam kedudukannya sebagai hamba akan kembali kepada Muslim itu sendiri (al-maqsū̄d bi taklîf al-a'yān busül al-maslahah li kull wähid min almukallafin). ${ }^{7}$ Setidak-tidaknya, Muslim yang konsisten dan sungguhsungguh dalam menjalankan tanggung jawab taklifi akan dapat menjaga kesinambungan pemenuhan kebutuhan primernya (al-hajjāh al-darürìyah), terjaga agamanya, rasionalitasnya, jiwanya, keturunannya, dan harta bendanya. ${ }^{8}$ Sangat mustahil, misalnya, orang yang tidak konsisten pengabdiannya kepada Tuhan dengan menjadi pecandu narkoba dan minum-minuman keras akan dapat menjaga kebutuhan primernya tersebut.

Untuk menjaga konsistensi pengabdian kepada Tuhan yang berdampak pada menjaga kesinambungan pemenuhan kebutuhan

\footnotetext{
${ }^{6}$ al-'Ā $\lim$, al-Maqāsid al-Āmmah, 83.

7 'Umar b. Șālih b. 'Umar, Maqāsid al-Shari'ah 'ind al-Imām Izz. b. 'Abd al-Salām (Ardan: Dār al-Nafā'is, 2003), 290.

8 Muhammad al-Ṭāhir b. 'Āshūr, Maqāsid al-Sharīáh al-Islāmīyah (Ardan: Dār alNafā'is, 2001), 301.
} 
primer di atas, maka dirumuskan berbagai produk hukum tanggung jawab taklifi (al-aḅkäm al-taklifizah). Secara definitif, hukum taklifi merupakan seperangkat aturan yang berisikan tentang perintah kepada setiap Muslim untuk melakukan atau tidak melakukan sesuatu, termasuk pula memilih untuk mengerjakan atau tidak mengerjakan. ${ }^{9}$ Perintah untuk melakukan misalnya salat (Q.S. al-Baqarah [2]: 43), puasa (Q.S. al-Baqarah [2]: 183), zakat (Q.S. al-Tawbah [9]: 103), dan seterusnya. Sementara perintah untuk tidak melakukan sesuatu, misalnya, ditunjukkan oleh larangan melakukan pembunuhan (Q.S. alAn‘ām [6]: 151), memakan bangkai, darah, dan daging babi (Q.S. alMāidah [5]: 3), mencela orang lain (Q.S. al-Ḥujurāt [49]: 11), dan seterusnya. Sedangkan perintah untuk memilih untuk melakukan atau meninggalkan sesuatu, misalnya, hukum meringkas jumlah rekaat salat di kancah peperangan (Q.S. al-Nisā' [4]: 101), berburu setelah berakhirnya pelaksanaan ibadah haji (Q.S. al-Māidah [5]: 2), dan seterusnya.

Tidak semua umat Muslim memiliki kemampuan untuk memahami hukum-hukum taklifì yang termuat dalam al-Qur'ān dan al-Sunnah. Di dalam al-Qur'ān, hukum taklïfi bertebaran dalam berbagai surah yang sangat banyak jumlahnya. Selain itu, pengungkapan konstruksi hukum yang terdapat dalam al-Qur'ān juga membutuhkan pengetahuan lintas disiplin. Sama halnya dengan Hadīth-hadist tentang hukum yang sifatnya menyebar, sehingga juga membutuhkan keahlian khusus dalam memahami dan merekonstruksinya sebagai produk hukum taklifi. Oleh karena itu, para ulama memberikan jalan keluar dengan merumuskan disiplin ilmu yang memudahkan umat Muslim untuk memahami produk hukum dalam al-Qur'ān dan Hadìth, sehingga lahir disiplin ilmu ushul figh, kaidah fiqh, dan fiqh.

Sebagaimana yang berlaku umum, dalam perspektif ketiga disiplin keilmuwan di atas, dikenal lima ketentuan hukum sharīah yang berkaitan dengan amal perbuatan setiap manusia. Secara deskriptif, kelimanya meliputi wajib, haram, sunnah, makruh, dan mubah. AlSha'rānī memberikan penjelasan tentang kelima hukum taklifi tersebut, dengan mengatakan:

Amal perbuatan manusia (dalam kaitan dengan hukum shari'ah) dapat dijelaskan sebagai berikut: Jika membawa kerusakan maka

${ }^{9}$ Wahbah al-Zuhaylī, al-Waj̄̄̌ fì Ușūl al-Fiqh (Beirut: Dār al-Fikr al-Mu'āṣir, 1999), 121. 
haram hukumnya seperti perbuatan zalim dan semacamnya. Jika meninggalkannya akan berakibat pada kerusakan, maka wajib hukumnya seperti berbuat adil. Jika mencakup kemaslahatan, maka termasuk sunnah seperti berbuat kebajikan. Jika meninggalkan berakibat pada kemasalahatan, maka makruh hukumnya. Jika tidak menghadirkan kemaslahatan dan kerusakan, maka termasuk mubah. ${ }^{10}$

Kelima varian hukum taklifi di atas mengikat kepada seluruh rangkaian aktivitas penghambaan kepada Tuhan dengan sedetail mungkin. Aktivitas penghambaan dalam bentuk salat, misalnya, menghadirkan ragam aktivitas lain yang cukup detail diatur oleh sharí'ah Islam, mulai dari syarat, wudu, tayamum, rincian tentang rukun salat dan seterusnya. Pada setiap aktivitas tersebut selalu hadir kelima varian hukum taklifi untuk menjadi panduan yang boleh dilakukan atau sebaliknya. Demikian pula, panduan tentang adanya pilihan untuk melakukan atau meninggalkan. Misalnya, aktivitas berwudu hanya boleh dilakukan dengan menggunakan air atau bertayammum dengan menggunakan debu. Konsekuensinya, berwudu dengan menggunakan angin yang dirasakan dapat mengakibatkan bukan saja tidak sah status wudunya, melainkan juga haram dilakukan. Sama halnya dengan pedoman tentang waktu pelaksanaan salat yang juga diatur secara ketat berikut ketentuan hukum taklifi-nya. Oleh karena itu, tidak sah dan haram hukumnya, misalnya melakukan salat fajar atau subuh pada waktu menjelang terbenamnya matahari.

Sebagai hamba Tuhan, setiap manusia terikat dengan ketentuan hukum sharíah taklifi tersebut sebagai bentuk ketaatan kepada-Nya. Ketaatan akan pudar atau mengalami penurunan kualitasnya, ketika hamba tidak lagi konsisten menyeralaskan sikap dan perilakunya dengan kelima hukum sharīah tersebut. Apalagi mereka yang merubah kelima ketentuan yang sudah disepakati oleh mayaoritas ulama. Misalnya, hukum minuman keras, berzina, dan telanjang bulat tidak menutup aurat yang telah dipastikan haram hukumnya, dibalik hukum menjadi mubah, sunnah, atau wajib. Mengubah ketentuan hukum dalam kasus tersebut sama halnya dengan menegasikan dimensi kehambaan dalam diri manusia, ${ }^{11}$ karena kelima ketentuan

\footnotetext{
10 'Abd al-Wahāb al-Sha'rānī, Minhāj al-Wuṣūl ilā Maqạsid Tlm al-Ușūl (Kairo: Dār alFattāḥ li al-Dirāsah wa al-Nashr, 2013), 265.

11 al-Sha'rānī memberikan contoh kasus diturunkannya Adam dan Hawa dari surga, sebagai akibat dari perilaku keduanya yang menghilangkan dimensi kehambaan di hadapan Tuhannya. Tidak hanya pelaku utamanya, pihak yang membantu pun juga
} 
pada dasarnya menjadi rambu yang menjadi pijakan manusia agar tetap dapat menjaga kedudukannya sebagai hamba di hadapan Tuhannya.

\section{Wahidiyah dan Negasi Dimensi Kehambaan}

Dalam tradisi sufisme, negasi dimensi kehambaan dalam kerangka ketaatan kepada Allah dikenal luas dengan terminologi "gugurnya berbagai kewajiban" (suqüt al-taklij) atau ketiadaan tanggung jawab ('adam al-takliff) sebagai seorang hamba terhadap Tuhannya. Dalam lingkup ini, setiap individu Muslim terbebas dari tanggung jawab mentaati ketentuan hukum-hukum sharī'ah yang mengikat (aḅkam alshari al-taklifí). Konsekuensi dari negasi, maka berlaku hukum "serba boleh" dalam mengartikulasikan tanggung jawab tersebut. Lima varian hukum taklifi yang seharusnya menjadi ruh dalam perilaku individu dapat diabaikan begitu saja. Konsekuensinya, negasi membolehkan manusia menghalalkan, mensunnahkan, memakruhkan sesuatu yang seharusnya berdasarkan ketentuannya adalah haram.

Pengabaian terhadap hukum taklifi tetap mendudukannya sebagai hamba ('abd) adalah menarik dicermati. Dalam perspektif sufisme, hamba dihadapan Tuhannya memikul tanggung jawab (taklif) yang sangat berat. Kehambaan tidak hanya dimanifestasikan kedalam bentuk pelaksanaan tanggung jawab normatif terhadap kesungguhan dan konsistensi mentaati ketentuan kelima varian hukum taklïfi di atas. Dalam perspektif Ibn 'Arabī, kehambaan memiliki makna yang sama dengan hamba yang keduanya bukanlah menunjuk pada sebuah nama, melainkan pada sifat yang melekat dalam diri manusia dihadapan Tuhannya. Hal ini berbeda dengan perspektif fiqh yang memposisikan hamba merupakan nama lain dari manusia, termasuk yang beragama Islam (Muslim). Oleh karena berkedudukan sebagai sifat, maka hamba dimaknai sebagai "kehinaan" (tadhallul) dan "keterbutuhan" (iftiqār). Perspektif ini didasarkan atas tafsir terhadap Q.S. al-Dhāriyāt [51]: 56.

mendapatkan akibat yang ditimbulkan dari negasi terhadap kehambaan tersebut. Tegas dinyatakan bahwa Adam bukan saja diharamkan memakan buah khuldi, tetapi juga mendekatinya. Hukum taklif tersebut untuk menjaga kesungguhan dan konsistensi ketaatan Adam sebagai hamba. Namun, hukum tersebut dilanggarnya dan itu berarti, ia tidak lagi mampu menjaga dimensi kehambaannya. Sedangkan Hawa, karena membantu atau setidaknya terlibat, ia juga mendapatkan akibat yang sepadan. Keduanya tidak lagi taat dan oleh karena itu, sebagai kafaratnya dikeluarga dari kenikmatan surga. 'Abd al-Wahāb al-Sha'rānī, Irshād al-Ṭălibìn ilā al-Marātib alUlamā’ al-Āmilìn (Kairo: Dār al-Karāz li al-Nashr wa al-Tawzī‘, 2006). 
Lafal illā liya'budūn tidak sekadar diterjemahkan sebagai "supaya kalian menyembah-Ku", melainkan juga sekaligus "supaya kalian menghinakan diri kepada-Ku" (li-yudhillu li), "supaya kalian merendahkan diri" $\left(k, b u d h u^{-}\right)$atau "membutuhkan-Ku"." Relasi antara pelaksanaan tanggung jawab taklifi dengan sifat kehinaan, rendah diri, dan keterbutuhan dengan Tuhannya mestinya lebih menempatkan manusia sebagai hamba lebih berhati-hati dalam memanifestasikan tanggung jawab taklifi-nya.

Negasi dimensi kehambaan yang berakibat pada tidak berlakunya ketentuan hukum sharíah yang taklifi di kalangan pengamal Wahidiyah, ketika perjalanan sufistiknya telah memasuki fase fanä' $f \grave{\imath}$ Dhät Allăh. Dalam fase ini, apapun yang diucapkan dan dilakukan tetap sebagai manifestasi dari bentuk ketaatan kepada Allah. Dalam satu teks dinyatakan:

Istighräq ahadìyah atau fanä' fi al-Dhät yang sebenarnya itu tidak menafikan hukum sharí‘ ah. Karena seseorang ketika mengalami fanā' fì al-Dhät yang sebenarnya (bukan pura-pura fanā') dia dikenai hukum shari sama dengan orang yang hilang akalnya (ghayr mukallaff), sehingga apa saja yang dia ucapkan sekalipun kalimat anà al-ḥaqq misalnya, dia tidak terkena hukum kufur karena dia dalam kondisi tidak mukallaf menurut pandangan hukum shar ì. Akan tetapi ketika dia sudah saḅw (normal bashariyah-nya) dia dikenai hukum sharì lagi, sehingga ketika dalam kondisi saḥw (normal basharyyah-nya) dia tidak boleh mengatakan atau mengajarkan rasa atau pengalaman yang dia alami ketika fanä' terutama yang bermuatan nafy al-khalq wa nafy al-shar $i_{i}^{13}$

Penegasan di atas menggambarkan, Wahidiyah meyakini dan mengakui adanya negasi untuk tidak terikat dengan hukum-hukum shari'ah, meskipun dengan batasan yang ketat. Negasi hanya berlaku bagi pengamal yang telah mencapai istighräq ạ̣adìyah atau fanà fì alDhät. Dalam panduan Wahidiyah ditegaskan, istighrāq aḅadìyah dipahami sebagai "tenggelam dalam ke-Esa-an Tuhan". Doktrin ini didefinisikan sebagai: mushähadat al-qalb (terbukanya hati) atau mukäshafah sampai mengalami fanā' fì Dhät Alläh dengan rasa dalam i'tiqäd (dhawqiyah i'tiqädìyah) yang tidak mungkin bisa diuraikan dengan susunan kalimat apapun. Tapi hatinya merasakan adanya, dan

12 Su'ād al-Hakīm, al-Mu'jam al-Süfìyah: al-Hikemah fì Hudūd al-Kalimah (Beirut: Dandarah li al-Tibā'ah wa al-Nashr, 1981), 765.

13 DPP PSW, Penjelasan tentang Hal-hal yang Sering Dipermasalabkan dalam Wabidiyah (Jombang: Dewan Pimpinan Pusat Penyiar Sholawat Wahidiyah, t.th.), 18. 
dhawqiyah tersebut tidak akan bisa dirasakan oleh orang lain yang tidak dikaruniainya. ${ }^{14}$

Untuk menggapai fase istighräq abadìyah, konsistensi dan kesungguhkan melakukan mujähadah mutlak harus dilakukan. Mujāhadah merupakan rangkaian aktivitas pembacaan Sholawat Wahidiyah yang dicipta oleh KH Abdul Madjid Ma'ruf. Secara garis besar, mujahädah terbagi menjadi tiga kateori, yaitu mujähadah umum, khusus, dan karena kebutuhan-kebutuhan khusus (waqtīyab). ${ }^{15}$ Masingmasing dari ketiga kategori mujähadah ini juga diderivasikan lagi menjadi berbagai bentuk aktivitas, namun tetap dengan menggunakan bacaan dan prosedur yang sama.

Proses pendakian menuju fase istighrāq aḥadīyah melalui berbagai aktivitas mujāhadah, setelah pembacaan Sholawat Wahidiyah selesai dan sebelum doa. Di tengah-tengah keduanya, istighrāq dilakukan dengan cara sebagai berikut:

Berdiam lahir dan batin tidak membaca atau mewiridkan apa-apa.

Segala konsentrasi pikiran, perhatian, perasaan, penglihatan, pendengaran dan sebagainya diarahkan tertuju kepada Allah. Tidak ada acara kepada selain Allah! Hanya Allah! Titik! Bukan kepada lafadh Allah! Tetapi Allah_-Tuhan! Ada yang menggunakan istilah: Là mawjūd illà Alläh (tiada yang wujud selain Allab). Artinya, karena kuatnya konsentrasi hanya kepada Satu, yakni Allah, maka yang lainlain atau makhluk tidak kelihatan. Tidak kelihatan oleh pandangan mata hati. Bukan pandangan lahir. Yang kelihatan hanya Allah. DiriNya sendiri tidak kelihatan. Sehingga mudahnya dikatakan, selain Allah tidak wujud, yang wujud hanya Allah. ${ }^{16}$

Selain pada saat mujāhadah, pencapaian istighrāq juga dapat dilakukan melalui latihan spiritual pengamal secara sungguh dan konsisten, di setiap ada kesempatan. Prosedur pelaksanaannya sama dengan proses di mujähadah, hanya yang membedakan pada bentuk keterlibatan pengamal. Jika dalam mujähadah, pencapaian istighrāq dipandu oleh pengamal yang pernah mendapat didikan langsung dari pengarang (KH Madjid), sedangkan di luar mujāhadah menempatkan pengamal sebagai pelaku secara otonom.

K.H. Abdoel Madjid Ma'roef Muallif (pengarang) Sholawat Wahidiyah sering menganjurkan supaya banyak melakukan latihan

\footnotetext{
${ }^{14}$ Ibid.

15 DPP PSW, Tuntunan Mujahadah dan Acara-acara Wabidiyah (Jombang: Dewan Pengurus Pusat Penyiar Sholawat Wahidiyah, 2015).

${ }^{16}$ DPP PSW, Penjelasan tentang Hal-hal, 20.
} 
istighrāq ahadìyah di mana saja ada kesempatan, tidak hanya ketika mujāhadah Wahidiyah saja. Hal itu bisa dilakukan pasca-salat maktūbah, waktu malam hari, dalam situasi yang tenang, waktu sidem kayon, waktu-waktu istirahat di sawah, di ladang, di atas kendaraan dan sebagainya. Kesan gunanya besar sekali bagi bertambahnya kebagusan di dalam hati. Selain itu, banyak dikaruniai ragam pengalaman sirri, pengalaman batin di dalam istighrā a ạ̣adīyah ini. ${ }^{17}$

Rentang waktu pengamal dalam fase istigbräq aḥadiyah karena bertumpu pada pengalaman personal sangat relatif. Bagi yang masih pemula dan ditambah latihan spiritual yang kurang bersungguhsungguh, bisa jadi hanya sesaat atau dalam jangka waktu yang sangat singkat dan bahkan tidak pernah menemukan fase tersebut. Sebaliknya, pengamal yang telah mencapai pendakian puncaknya, terbuka mendapati fase istighräq ahadīyah pada rentang waktu cukup lama, bisa jadi sepuluh menit dan lebih lama lagi. ${ }^{18}$

Bagi pengamal yang mencapai fase istighräq ahadìyah, statusnya menjadi orang yang terbebas dari tanggung jawab sebagai hamba Tuhan (ghayr mukallaf). Dalam tradisi sufi, Muslim yang terbebas dari ketentuan sharī'ah disebut dengan istilah majdhüb. Dalam terminologi sufisme, majdhüb didefinisikan sebagai orang yang menerima tarikan ilahi yang dikehendakinya-Nya, agar semakin lebih kepada-Nya tanpa melalui perjalanan spiritual yang berliku. ${ }^{19}$ Majdhüb berasal dari akar kata jadhaba yang bermakna "menarik, memikat, menawan (hati), memindah dari suatu tempat, cepat, atau sebuah jarak". Dari makna dasar ini, Anwar Fuad Ab̄̄ Khazām menggambarkan jadhāb sebagai "tertariknya ruh, kenaikan (tingkatan spiritual) hati, terbukanya pintupintu rahasia ilahi, munājät, dan lain-lain, semata-mata karena tawfí dan "ināyah-nya". 20

Para sufi yang mencapai fase majdhūb memiliki status yang "gila namun berakal" (junūn al-uqalā). Dari perilaku-perilaku zahir yang aneh menurut perspektif masyarakat dianggap merepresentasikan "kegilaan", namun tetap memiliki kesadaran terhadap eksistensinya dirinya. Oleh karena gila namun berakal, maka kebanyakan dari

\footnotetext{
17 DPP PSW, Kuliah Wabidiyah (Jombang: Dewan Pimpinan Pusat Penyiar Sholawat Wahidiyah, 2005), 152.

18 Ibid.

19 In'amuzzahidin Masyhudi, Wali Sufi Gila (Yogyakarta: Penerbit Ar-Ruzz Press, 2003), 27.

${ }^{20}$ Ibid.
} 
mereka dapat berinteraksi sosial bersama masyarakat dengan baik, dan tidak jarang mereka memberikan manfaat yang luar biasa kepada lingkungan sekitarnya. Kesimpulannya, sufi yang majdhüb tetap mampu mempertahankan eksistensinya sebagai manusia etis secara individual dan sosial. ${ }^{21}$

Dengan statusnya sebagai ghayr mukallaf, pengamal Wahidiyah yang mencapai istighrāq aḥadīyah lepas dari dimensi-dimensi kehambaan. Konsekuensinya, keseluruhan perilakunya yang kasat mata dan melanggar ketentuan hukum sharíah taklifi, tetap saja tidak menghalanginya mendapatkan status sebagai Muslim yang taat. Sebagaimana dalam kutipan di atas, pernyataan sufi terkenal al-Ḥallāj digunakan sebagai analoginya. Pernyataan Anā al-Haqq (Saya adalah Tuhan) yang terlontar dari mulut al-Halläj tidak menyebabkannya berstatus kafir, karena ia dalam kedudukan sebagai majdhūb, dan dengan demikian, ghayr mukallaf.

Secara kategoris, majdhüb-nya pengamal Wahidiyah bukan datang tiba-tiba, melainkan melalui proses yang cukup panjang dan berliku, kesungguhan, dan konsistensi para pengamalnya. Oleh karena itu, majdhüb termasuk dalam kategori yang muktasab (berdasarkan usaha). ${ }^{22}$ Setidak-tidaknya selain mujähadah dan latihan spiritual untuk mendapatkan istighräq ahadìyah secara mandiri, dan menjalani serangkaian tata krama, sebagaimana yang banyak dilakukan oleh sälik atau murid. Ketiga proses ini harus dilakukan secara simultan, karena mujähadah yang konsisten dan sungguh-sungguh, misalnya, tetap tidak akan mampu mengantarkan pengamal sebagai mustaghriq, selama hati masih sarat dengan kemaksiatan.

Penaatan hati menjadi syarat mutlak pencapaian istighrāq, karena ia yang mengendalikan pikiran, sikap, dan perilaku pengamal. Selain itu, kemaksiatan hati meskipun dalam derajat yang sangat kecil kualitasnya memiliki implikasi luas bagi pembentukan perilaku sufistik pengamal Wahidiyah. Dalam konteks ini, Kiai Madjid yang juga pendiri Wahidiyah pernah mengatakan: "Setitik maksiat batin lebih buruk

\footnotetext{
${ }^{21}$ Ibid., 31-32.

22 Dalam khazanah sufi, dikenal dua kateori majdhüb yang menyebabkan sälik atau murid berstatus ghayr mukallaf (terbebas dari ketentuan hukum sharīah), yaitu: majdhüb yang ghayr muktasab (tanpa usaha) dan muktasab (melalui usaha). Kateori pertama, majdhüb memperoleh tarikan ilahi secara langsung, tanpa usaha atau susah payah melakukan pendakian sufistik. Kategori kedua, majdhüb yang mendapatkan tarikan ilahi melalui usaha serius dan konsisten dalam bermujahadah, baik melalui jalan sulük atau tarekat maupun lainnya. Ibid., 36.
} 
daripada segunung maksiat yang dilakukan oleh anggota tubuh secara kasat mata". ${ }^{23}$

Untuk membersihkan hati dari ragam kemaksiatan, terdapat beberapa tata krama yang harus dilalui oleh setiap pengamal Wahidiyah. Syukur, ikhlas, sabar, rida, tawakal, mahabbah, dan husn alzann merupakan ragam tata krama yang mutlak bagi pengamal Wahidiyah untuk mendalami dan dan mengartikulasikannya dalam kehidupan sehari-hari. Bagi Wahidiyah, ragam tata krama dimaksud merupakan pilar yang memberikan pengaruh bagi berbagai tata krama lain yang dikenal luas dalam tradisi sufisme. Ketujuh varian tata krama juga dapat menjadi indikator untuk mengukur kebahagiaan dan kesengsaraan, kemuliaan atau kehinaan setiap Muslim, terutama pengamal Wahidiyah. ${ }^{24}$

Bagi Wahidiyah, syukur dimaknai sebagai ungkapan rasa terima kepada Tuhan atas nikmat penciptaan (ni'mat al-ijäd) dan pemeliharaan (ni'mat al-imdäd). Dalam bentuk praksisnya, terdapat empat cara artikulasi rasa syukur pengamal Wahidiyah kepada Tuhannya. Pertama, menyadari dan merasakan sepenuhnya bahwa dirinya benar-benar mendapatkan anugerah dari Tuhan. Kedua, menyadari, meyakini, dan memahami hanya Tuhan sebagai satu-satunya Dzat yang memberikan nikmat. Ketiga, mengungkapkan rasa syukurnya secara terbuka dengan lisannya, misalnya, dengan mengucapkan al-hamd li Alläh atau kata maupun kalimat-kalimat yang berisikan sanjungan dan terima kepada Tuhan. Keempat, mendaya gunakan nikmat yang berikan, terutama yang berupa materi-finansial kepada jalan atau perilaku yang diridai oleh Tuhan. ${ }^{25}$

Ikhlas menunjuk pada sikap yang termanifestasikan kedalam perilaku pengamal agar seluruh aktivitasnya di dunia, terlebih yang berhubungan dengan pendakian sufistik, mujähadah, dan berlatih mencapai istighräg abadiyah semata-mata mencari rida Allah, tanpa pamrih untuk mendapatkan balasan baik di dunia maupun akhirat. Secara bertahap, pengamal yang menapati tiga tahapan keikhlasan agar memperoleh wussul kepada Allah. Tahapan pertama, ikhlasnya orang yang taat beribadah dengan jalan menyerahkan sepenuhnya segala bentuk ibadahnya hanya semata-mata karena Allah. Dalam konteks ini, pengamal harus menghindarkan ibadahnya dalam kerangka

\footnotetext{
${ }^{23}$ DPP PSW, Kuliah W abidiyah, 155.

${ }^{24}$ Ibid., 182-215.

${ }^{25}$ Ibid., 182-186.
} 
mengejar pahala, mendapatkan surga, menghindari neraka, dan seterusnya. ${ }^{26}$

Sabar menunjuk pada sikap batin pengamal untuk selalu tabah dalam menerima ujian atau cobaan dari Tuhan. Terdapat tiga manifestasi sabar yang harus diartikulasikan oleh seluruh pengamal Wahidiyah. Pertama, sabar terhadap musibah yang berarti harus selalu tabah dan tahan uji dalam menghadapi segala ujian maupun cobaan hidup yang berkaitan dengan kehidupan dunianya sehari-hari, misalnya, berkaitan dengan ekonomi, kesehatan, keluarga, dan seterusnya. Kedua, sabar dalam ketaatan yang berarti setiap pengamal harus selalu konsisten dan bersungguh-sungguh dalam menjalankan ketaatan kepada Tuhannya dengan tidak terpengaruh oleh berbagai halangan dan rintangan. Ketiga, sabar dari maksiat yang dimanifestasikan dalam bentuk perilaku yang tidak akan terpengaruh oleh berbagai bentuk kemaksiatan. Sekalipun, mereka mendapatkan ancaman atau tekanan dari pihak lain, karena penolakannya terhadap kemaksiatan tersebut. ${ }^{27}$

Rida yang bagi pengamal Wahidiyah dimaknai sebagai perasaan puas terhadap ketentuan dan kepastian Tuhan dalam kondisi apapun. Hanya saja perasaan tersebut harus disertai dengan usaha sungguhsungguh untuk menemukan jalan keluar atas berbagai permasalahan yang dihadapi pengamal. Selain itu, rida juga harus menyertakan sikap penyerahan diri secara total kepada Tuhan. Keberhasilan dalam mengurai benang kusut kehidupan pengamal, semata-mata bukan karena usahanya melainkan sepenuhnya merupakan pertolongan dari Tuhan.

Mahabbah merupakan sikap mencintai sepenuhnya bukan saja kepada Tuhan, melainkan juga para rasul, nabi, malaikat, generasi salaf yang salih, keluarga dan para sahabat nabi, dan seluruh makhluk ciptaan-Nya. Bagi Wahidiyah, tidak mungkin sempurna cintanya kepada Tuhan selama pengamal tidak mencintai ciptaan-Nya dengan sepenuh hati. Namun, cinta kepada selain Tuhan semata-mata hanya ditujukan untuk mencintai Tuhannya, bukan karena dorongan nafsu, pujian, sanjungan, dan motif-motif keduniaan lainnya. ${ }^{28}$

Baik sangka (ḅusn al-zann) dan berkeyakinan positif (ḅusn al-yaqin) juga menjadi sikap yang harus termanifestasikan kedalam kehidupan

\footnotetext{
${ }^{26}$ Ibid., 186-191.

27 Ibid., 191-197.

${ }^{28}$ Ibid., 201-210.
} 
sehari-sehari pengamal Wahidiyah. Baik sangka menunjuk pada sikap batin yang selalu berpikir positif terhadap dunia eksternal pengamal dengan menghindari sikap penuh curiga kepada sesama makhluk. Bahkan, kepada Tuhan dan Rasul-Nya, bukan saja berbaik sangka tetapi juga harus disertai dengan berkeyakinan positif. Tidak ada satu pun yang salah terhadap ketentuan dan kepastian yang datang dari Tuhan adalah manifetasi dari keyakinan positif terhadap-Nya. Kepada para Rasul, pengamal juga harus berkeyakinan bahwa risalah kerasulan dan kenabian maupun kepribadian yang melekat dalam setiap Nabi dan Rasul merepresentasikan kebenaran mutlak. ${ }^{29}$

Untuk mempercepat proses pembersihan hati dari kemaksiatan dalam berbagai bentuknya, kitab al-Hikam karya Ibn 'Ațā Allah alSakandarī juga menempati peran penting. Untaian-untaian hikmah dalam kitab tersebut diyakini akan memberikan kontribusi penting bagi proses pembersihan hati, jika diimplementasikan secara sungguhsungguh dan konsisten. Kiai Madjid sendiri menggunakan al-Hikam sebagai sumber utama untuk memberikan ragam wejangan pembersihan hati melalui pengajian regular. Muhammad Ruhan Sanusi-salah satu santri utama Kiai Madjid mengatakan-pengajian dilakukan setiap hari Ahad pagi secara regular, dan rata-rata selesai (khätam) dua tahun setiap periode. Pasca-khatam, pengajian dimulai lagi dari awal dan begitu seterusnya hingga Kiai Madjid wafat. ${ }^{30}$ Tradisi Kiai Madjid ini juga diteruskan oleh para tokoh-tokoh penting Wahidiyah terutama yang pernah berguru langsung kepadanya. Mereka di tempatnya masing-masing juga menyelenggarakan pembedahan terhadap substansi sufistik al-Hikam melalui aktivitas pengajian regular.

\section{Negasi Kehambaan dalam Kerangka Sufisme}

Kehambaan dalam diskursus tasawuf merupakan bidang kajian yang cukup signifikan. Keseluruhan doktrin sufisme baik dari kutub sunni maupun falsafi tentang eksistensi manusia berhulu pada doktrin kehambaan. Doktrin ini meneguhkan bahwa, setiap Muslim dalam menjalani kehidupannya di dunia hanya semata-mata diproyeksikan untuk memanifestasikan dirinya sebagai hamba di hadapan Tuhannya. Dalam tradisi tasawuf, kehambaan tidak hanya terhenti pada manifestasi eksoteris dan esoteris.

\footnotetext{
${ }^{29}$ Ibid., 210-215.

${ }^{30}$ Huda, Tasawuf Kultural, 11.
} 
Bagi Wahididiyah, tarikan ilähìah yang menyebabkan pengamalnya menjadi wusūl kepada Allah dan menyebabkan berubahnya status dari mukallaf (penerima beban tanggung jawab sebagai hamba) menjadi ghayr mukallaf (kebebasan dari tanggung jawab sebagai hamba) tetap dalam bingkai ortodoksi sufisme. Bagi mereka, terdapat sumber yang digunakan sebagai rujukan termasuk karya-karya komentar terhadap kitab al-Hikam Ibn 'Ațā' Allah, seperti Sharḅ Ibn Ibäd, Iqqäz al-Himām, dan seterusnya. Demikian pula, tarikan ilähìyah pada saat pengamal mengalami fase fanā' juga diurai oleh Jāmi U Ușül alAwliyyā' karya Dhiyā' al-Dīn Aḥmad Muștafāa al-Naqshabandī, al-Kashf 'an Haqiqat al-Süfìyah oleh Mạ̣mūd 'Abd al-Raūf al-Qāsim, Mafätị̣ alGhayb karya Fakhr al-Dīn al-Rāzī, dan seterusnya. ${ }^{31}$

Ibn 'Ațā' Allah menegaskan, "barangsiapa yang benar-benar mengenal Allah, maka pasti dapat melihat-Nya pada tiap-tiap sesuatu" (man 'arafa al-haqq shähadah fi kull shay') dan "barangsiapa yang fanä' dengan Allah, maka ia pasti lupa dengan segala sesuatu" (man faniya bih ghäba 'an kull shaiy). ${ }^{32}$ Pernyataan ini menunjukkan, setiap sufi yang telah mengalami kefana'an, maka ia dan seluruh inderawinya akan tidak lagi mampu melihat dirinya dan seluruh makhluk lainnya, kecuali Allah semata.

Ibn 'Ajībah al-Hasanī dalam komentarnya yang terkenal terhadap kitab al-Hikam mengatakan, "orang yang fanà' adalah majdhüb dalam kefanaannya" (al-fäni majdhüb fì maqām al-fanā). Ia mendapatkan anugerah berupa tarikan ilähìyah, sehingga dirinya tidak akan mampu menentapkan sesuatu selain Allah dan tidak akan melihat apapun selain Allah. ${ }^{33}$ Pengamal Wahidiyah dalam fase ini hilang jati dirinya dan mengalami situasi yang luar biasa, karena terkena tarikan hakikat fan $\bar{a}$ ' ke dalam Dzat yang Maha Besar dan Tinggi dan keluar dari kebiasaan yang akan menghilangkan segala rasa kemanusiaannya (istibläk al-ḅissi fi dubürī al-ma'nâ)..$^{34}$

Dalam fase ini, maka ketentuan-ketentuan sharíah yang sudah berlaku umum nyaris tidak berlaku lagi di bagi orang yang sedang fan $\vec{a}$

${ }^{31}$ DPP PSW, Penjelasan tentang Hal-hal, 20.

32 Salim Bahreisy, Tarjamah Hikam li al-Syaikh Abmad Ibn Athäillah al-Sakandari (Surabaya: Penerbit Balai Buku Surabaya, 1980), 132.

33 Aḥmad b. Muhammad b. 'Ajībah al-Hasanī, İāa al-Himam fi Sharh al-Hikam (Kairo: Dār al-Ma‘̄ārif, 1983), 371.

34 'Abd Allah Aḥmad b. 'Ajībah, Míräj al-Tashawnuf ilā Haqāiq al-Tasawwuf (Kairo: D à r al-Bayḍ̄̄', t.th.), 59 . 
dalam jadhab-nya. Jika menggunakan perspektif al-Sha'rānī, pengamal Wahidiyah dalam fase fäni al-madjbūb diyakini telah memiliki spiritualitas yang melebihi masyarakat awam atau telah berada pada derajat kewalian. Al-Sha'rān̄̄ menyokong penuh pendapat yang mengatakan, derajat kewalian yang dimiliki seseorang lebih sempurna dari pada derajat risalah dan kenabian. Alasannya, kewalian termasuk yang melekat pada fäni al-majdhüb memiliki orientasi yang menyeluruh dan melingkupi seluruh kenabian secara umum. Sedangkan nubumwah hanya tertentu pada pensharīahan dan risalah yang berlaku pada Nabi dan zaman tertentu. Karakter khas kewalian yang menyeluruh ini, Allah telah menetapkan kepada para wali atas kedudukan kenabian umum yang tidak ada lagi shari' ${ }^{-}$ah di dalamnya sekaligus mendapatkan anugerah memiliki kebebasan merumuskan sharī'ahnya secara mandiri melalui ijtihadnya dalam nenetapkan hukum. ${ }^{35}$

Kebebasan untuk menciptakan sharī'ah baru dengan melakukan serangkaian aktivitas hukum juga berlaku pada Rasul Muhammad. Sebagai Rasul, jika ia berbicara kaluar dari pensyariatan, maka hal itu dapat dilihat dari kedudukannya sebagai wali dan orang yang arif, karena kedudukannya tersebut menempatkannya lebih sempurna dan menyeluruh ketimbang sebagai Rasul atau yang memiliki sharī'ah. Penting dicatat bahwa, kewalian harus dilihat dari perspektif keadilan abadi (al-haqqānìah al-abadìah) yang tidak terputus oleh dunia dan akhirat. Berbeda dengan kenabian dan risalah yang keduanya terikat dengan umat tertentu dan ketentuan tertentu. ${ }^{36}$

Oleh karena itu, jika terdapat sufi yang fäni al-majdhüb berkata, bersikap, dan berperilaku yang keluar dari ketentuan sharíah tetap dianggap benar. Selain pernyataan Anà al-Haqq, terdapat banyak bukti yang menunjuk ungkapan-ungkapan yang secara kasat mata shari'ah tidak dibenarkan dan bahkan, menciptakan shari'ah baru. Hal ini pernah dinyatakan, salah satunya, oleh Ibn 'Arabī dalam syairnya yang sangat terkenal:

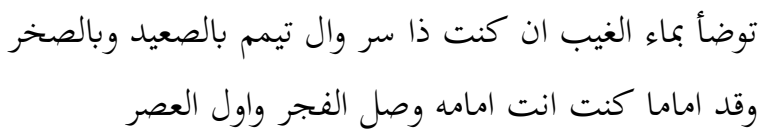

\footnotetext{
35 'Abd al-Wahāb al-Sha'rānī, "Shațahāt al-Ṣūfiyah al-Musammā bi al-Fath fî Ta'wīl mā Șadara 'an al-Kamāl min al-Shațah", dalam Abū Yazīd al-Bustāmīe al-Majmūah al-Süfìyah al-Kāmilah (Damaskus: Dār al-Madā li al-Nashr wa al-Tawzī', 2004), 125. 36 al-Sha'rānī, "Shațahāt al-Ṣūfiyah", 125-126.
} 


$$
\text { فهذى صلاة العارفين بركم فان كنت منهم فانصح البر بالبحر }
$$

Berwudulah dengan air yang tidak tampak, jika engkau memiliki keistimewaan tersembunyi. Jika tidak, bertayamumlah dengan debu dan pasir. Aku benar-benar telah dipilih menjadi imam dan kemudian engkau yang menjadi imamnya. Salat subuhlah di waktu awal salat asar. Hal ini adalah salatnya orang-orang yang arif dengan Tuhan mereka. Maka jika engkau menjadi bagian dari mereka, berilah nasehat kebaikan dengan lautan samudera." 37

Al-Sha'rān̄ menegaskan tidak ada ketentuan sharī'ah yang dilanggar dalam syair Ibn 'Arabī di atas. Menurunya, berwudu bukan hanya sekadar membersihkan anggota tubuh tertentu dengan air yang kasat mata. Bagi sufi yang sudah mencapai derajat kewalian, berwudu adalah membersihkan bagian-bagian dari sifat-sifatnya hati dari najisnajis maknawi dengan menggunakan air yang tidak kasat mata. Air yang tidak kasat mata adalah kemurnian tauhid, karena tanpa air tersebut, maka sulit bagi sufi untuk membersihkan hatinya. Syair juga memberikan penegasan, hanya sufi yang telah dibuka hijabnya yang dapat menduduki posisi sebagai imam. Salat fajar yang berlangsung pada waktu siang hari merupakan pembuka penglihatan setelah hijabnya kegelapan wujud terbuka. Asar bukan seperti yang dipahami dalam fiqh, melainkan menunjuk pada awal suatu masa atau permulaan dimulainya masa pencerahan. Dengan tegas al-Sha'rānī mengatakan Ibn 'Arabī dan pengikutnya dengan kreasi barunya terhadap shari'ah adalah "orang-orang yang tidak keluar dari ketaatannya terhadap hukum-hukum sharí'ah dalam setiap penglihatan ketuhanannya". 38

Untuk memperkuat argumen di atas, al-Sha'rānī dalam pernyataannya secara terpisah menyatakan, sharī'ah yang dipahami oleh Ibn 'Arabī dan pengikutnya adalah berbeda dengan yang diartikulasikan oleh umat Islam pada umumnya. Ia menegaskan shari'ah memiliki dua tingkatan yang pertama diperuntukkan secara

37 'Abd al-Wahāb al-Sha'rānī, Tabaqāt al-Kubrā al-Musammā Lawāqị̀ al-Anwār alQudsīyah fì Manāqib al-Ulamà' wa al-Süfiyah, Vol. 2 (Kairo: Maktabah al-Thaqāfah li alDininyah, 2005), 137.

38 al-Sha'rānī, Tabaqāt al-Kubra, Vol. 2, 137-138. Berbagai pemaknaan yang secara kasat mata keluar dari ketentuan hukum fiqh yang berlaku umum terhadap aspekaspek shari`ah Islam, namun dibenarkan bagi ahli hakikat dijelaskan secara panjang lebar dalam Ḥaidar al-Āmalī, Asrār al-Sharīah wa Atwār al-Ṭariqah wa Anwār alHaqiqah (Libanon: Dār al-Mụhijah al-Bayḍā', 2012). 
khusus bagi Muslim awam dan kedua bagi Muslim berkedudukan khusus. Hal ini sama dengan yang diterima oleh Nabi Muhammad dan dengan shari ${ }^{-}$ah yang diterimanya ia pun dapat memahaminya karena kekhususannya. Demikian pula, para sahabat menerima shari'ah yang hanya dapat dipahami oleh generasi sahabat yang tidak mungkin bagi tabiin untuk mencernanya. Begitu seterusnya. ${ }^{39}$

Argumen lain yang memperkuat keabsahan negasi kehambaan adalah kaidah yang berlaku umum di kalangan para sufi. Salah satu kaidah menegaskan, ketabuilah Allah dan jadilah sebagaimana apa yang engkau kehendaki (a'rif Allah wa kun kayf shi'ta). Keberlakuan kaidah ini didasarkan atas pengalaman di kalangan sufi bahwa, setiap orang yang telah makrifat kepada Allah, maka hatinya akan selalu bergantung kepadanya dan penuh sesak cinta kepada-Nya, sehingga akan muncul kelebihan yang tidak dimiliki oleh orang lain. ${ }^{40}$

Al-Sha'rānī juga memberikan banyak contoh perilaku yang secara kasat mata melanggar sharī'ah, namun tidak mengurani kedudukannya sebagai sufi yang telah memperoleh derajat kewalian. Pertama, Ibrāhīm al-'Uryān (w. $930 \mathrm{H}$ ) yang terlihat diatas mimbar sebuah masjid dan berkhotbah dengan telanjang bulat. Kedua, al-Sharîf al-Majdhūb yang pada waktu siang hari di bulan Ramadan, ia makan sesuka hatinya dan mengatakan bahwa dirinya adalah orang yang merdeka, karena Tuhan telah memerdekannya. Ketiga, Sha'ban al-Majdhūb yang menjelang akhir hayatnya, ia selalu membawa arak yang dicampur susu hingga kematiannya. Pada saat yang sama, ia juga tidak memakai pakaian yang menutup auratnya, kecuali dengan potongan-potongan kulit, sobekan kain, tanah liat atau bulu yang kempal untuk menutupi kemaluannya. Keempat, Khalīl al-Majdhūb (w. $900 \mathrm{H}$ ) yang selalu tidak berpakaian dan bahkan telanjang bulat. ${ }^{41}$

Pengakuan fäni al-majdhüb sebagai Muslim yang tetap dalam ketaatannya sebagai hamba di hadapan Tuhannya juga mendapatkan dukungan dari John Spencer Trimingham maupun Annemarie Schimmel. Bagi Trimingham, hubungan sufi yang telah mencapai derajat fäni al-majdbüb tidak seperti masyarakat pada umumnya. Oleh karena itu, secara horizontal ia tidak bertanggung jawab atas segala

39 'Abd al-Wahāb al-Sha'rānī, Latäif al-Minan wa al-Akblāq fì Wujūb al-Tahadduth bi alNi'mah 'ala al-Ithāq al-Ma'rūf bi al-Mī̄àn al-Kubrā (Damaskus: Dār al-Taqwā li alNashr wa al-Tawzī', 2004), 77.

40 'Àbd al-Halīm Mạ̣mūd, al-Madrasah al-Shädhilīyah al-Hadìthah wa Imāmubā Abū alHasan al-Shādhilì (Kairo: Dār al-Kutub al-Hadīthah, t.th.), 53.

${ }^{41}$ Masyhudi, Wali Sufi Gila, 90. 
ucapan dan tindakannya. Secara kasat mata, bisa jadi, ia melakukan perbuatan yang dianggap menyimpang dari ketentuan shari'ah oleh masyarakat kebanyakan. Namun, perbuatan dimaksud harus dilihat dalam kerangka ia sedang mengalami kehilangan kesadaran akibat lebur dan lenyap dalam keesaan ilahi. ${ }^{42}$ Sama halnya dengan Schimmel yang mengatakan:

Jadhab sebagai jalan spiritual sälik, menuju pengalaman ruhani yang lebih tinggi ketimbang jalur tariqah. Orang yang jadhab sering disebut sebagai orang "gila", yang hilang kesadaran dan perilaku normalnya. Hal itu terjadi, karena mereka terbenam dalam keesaan ilahi, yang membuat kagum sekaligus takut orang lain dengan segala ulahnya. Namun demikian, laku sufi majdhüb merupakan sisi gelap (the darker side) dunia sufi. Hal ini disebabkan karena keterkejutannya terhadap pengalaman mistik. Akal sehatnya terguncang, sehingga ia cenderung melakukan larangan agama, seperti berjalan mondarmandir dengan telanjang bulat. Disebabkan oleh akalnya yang hilang, sufi majdhüb terbebas dari hukum dan larangan-Nya. Ia hidup dalam perpaduan cinta yang sempurna dengan Tuhannya. ${ }^{43}$

Meskipun bukan dari kalangan Nabi dan Rasul, kedudukan manusia yang mencapai kewalian sebagaimana dideskripsikan di atas tetap memiliki kedudukan lebih tinggi dibanding nubuwwah dan risalah, sehingga potensi kesalahan sekecil apapun dapat dihindari. Manusia selain Nabi dan Rasul memang tidak memiliki sifat ma'șum, namun melekat dalam dirinya sifat mahfüz: ${ }^{44}$ Kedua kata ini memiliki makna yang sama, yaitu terjaga dari penyimpangan terhadap sharīah. Baik Nabi dan wali sama-sama tidak akan durhaka kepada Allah, hanya saja keduanya memiliki perbedaan yang sangat mendasar. Tidak ada kemaksiatan dalam diri Nabi, karena memiliki sifat "ismah yang telah dianugerahkan oleh Allah kepadanya. Konsekuensinya, Nabi yang telah dipilih tidak akan melakukan kemaksiatan, karena Allah memberinya kekuatan untuk menolak atau mencegahnya. Hal ini berbeda dengan wali yang tidak lain sama kedudukannya dengan manusia biasa. Ia memiliki potensi untuk untuk berbuat kemaksiatan atau mencederai ketaatannya. Namun, seorang wali akan mampu menghindari kemaksiatan tersebut, karena Allah telah memberinya

42 Ibid., 37.

${ }^{43}$ Ibid.

44 'Abū al-Qāsim 'Abd al-Karīm b. Hawāzin al-Qushayrī, al-Risālah al-Qushayrìyah, Khalīl Manșūr (ed.) (Beirut: Dār al-Kutub al-'Ilmīyah, 2001), 381. 
nur atau cahaya dalam hatinya, yang dapat memberinya petunjuk, dan sekaligus memalingkannya dari kemaksiatan tersebut. ${ }^{45}$

Dengan demikian, pengamal Wahidiyah yang sudah sampai pada fase fāni al-majdhūb dan telah memasuki wilayah kewalian, maka ia tetap menjadi Muslim yang tidak melanggar ketentuan shari'‘ah Allah. Sekalipun ia dalam kefanaanya mengungkapkan atau berperilaku yang melanggar ketentuan sharí'ah. Oleh karena pada fase ini, ia telah menempati derajat fawq al-nubuwwah wa al-risälah, sehingga membebaskannya dari tanggung jawab sebagaimana yang dimiliki oleh Muslim kebanyakan. Bahkan, ketika pengamal mengkreasi ragam shari`ah baru tetap saja menempatkannya sebagai Muslim yang taat di mata Allah. Dimensi kehambaan yang termanifestas ke dalam tanggung jawab taklifi berdasarkan ketentuan sharī'ah absah untuk dinegasikan. Dari sini, ketika pengamal sudah sampai pada fase istighrāq ahadìah memiliki otoritas untuk bertindak "serba boleh".

\section{Transformasi Negasi Kehambaan di Lembaga Pendidikan Formal}

Sebagaimana telah dideskripsikan sebelumnya, negasi kehambaan terjadi seiring dengan berlangsungnya proses istighräq ahadīyah yang dilakukan secara sungguh-sungguh dan konsisten oleh pengamal SW. Proses terjadinya istighrāq aḥadìyah tidak dilepaskan dari serangkaian aktivitas mujāhadah, baik kubrā, shabrìyah (bulanan), usbü ìyah (mingguan) maupun waqtiyah (temporal). Dengan bahasa lain dapat dikatakan, setiap pengamal yang melibatkan diri dalam aktivitas mujähadah maka dipastikan akan menemui fase istighrāq, sehingga berpotensi mengalami istighräq ạ̣adìyah yang berdampak pada negasi kehambaan dalam dirinya.

Dalam bentuk praksisnya, istighräq menjadi bagian tak terpisahkan dari mujāhadah, tepatnya, setelah membaca doa: ${ }^{46}$

$$
\text { اللهم بارك فيما خلقت وهذه البلدة يا الله وفي هذه المجاهدة }
$$

"Ya Allah, limpahkanlah berkah di dalam segala makhluk yang Engkau ciptakan dan di dalam negeri ini yaa Allah, dan di dalam mujähadah ini, Ya Allah!" (Dibaca tujuh kali).

Jika mujähadah dilakukan secara kolektif, maka imam setelah selesai doa di atas meminta untuk istighräq secara bersama. Namun, jika

\footnotetext{
${ }^{45}$ Masyhudi, Wali Sufi Gila, 69.

${ }^{46}$ DPP PSW, Kuliah Wabidiyah, 24.
} 
mujähadah dilakukan secara mandiri, maka pengamal langsung dapat melaksanakan istighräq. Tidak ada ketentuan pasti, berapa prosesnya berlangsung dan tergantung sepenuhnya pada imam (kolektif) atau pribadi pengamal (mandiri). Kemudian pengamal menindak lanjuti dengan pembacaan surah al-Fatihah sebanyak 1 (satu) kali.

Salah satu pusat aktivitas Wahidiyah di Jombang, tepatnya di pesantren al-Tahdzib Rejo Agung Ngoro, pada satuan-satuan pendidikan yang dikelolanya, seperti MTs Ihsaniyat, SMPIT Ihsaniyat, MA Ihsaniyat, dan SMK Ihsaniyat yang dikelolanya menjadikan mujāhadah secara berkala sebagai bagian tak terpisahkan dari proses penyelenggaraan kegiatan belajar-mengajar. Rangkaian aktivitas mujähadah selalu melibatkan seluruh komunitas sekolah, baik peserta didik, dewan guru, dan kepala sekolah. ${ }^{47}$

Transformasi mujāhadah kepada peserta didik di lembaga pendidikan formal diintegrasikan dengan materi-materi lain yang relevan. Termasuk di antaranya materi tentang dasar-dasar yuridis keagamaan tentang keabsahan SW, ragam pendapat ulama yang mendukungnya, tata cara pelaksanaan, hingga etika dalam mujāhadah. Transformasi semakin intensif dilakukan bagi peserta didik yang telah memasuki kelas akhir pada setiap satuan pendidikan, terutama pada jenjang menengah atas. Setelah selesai ujian, dilakukan pelatihan khusus yang mempersiapkan mereka agar menjadi lulusan yang tidak hanya menjadi pengamal, melainkan juga motor penggerak penyebaran Wahidiyah di wilayah masing-masing. Pendalaman tentang doktrin-doktrin dan berbagai problem yang terkait dengan opini kontroversial dari publik menjadi rangkaian materi dalam pelatihan tersebut. ${ }^{48}$ Dapat dipastikan bahwa, doktrin istighrāq di luar mujāhadah juga menjadi bagian yang harus dipelajari dan diimplementasikan oleh peserta didik.

Untuk memperkuat capaian transformasi melalui lembaga pendidikan formal, peserta didik yang berada di pesantren juga diharuskan terlibat aktif dalam berbagai bentuk mujähadah yang diselenggarakan oleh pesantren. Pertama, mujähadah yawmìah, dilaksanakan secara rutin dan intensif yang pelaksanaannya adalah setiap usai salat lima waktu. Kedua, mujāhadah usbūiyah yang

47 Rofiatul Hosna dan Imron Arifin, "Principal Spiritual Leadership in Strengthening Character Education Through the Teachings of Sholawat Wabidiyah at Vocational High School Ihsanniat Jombang Indonesia", Advances in Social Science, Education and Humanities Research, Vol. 128 (2017), 146-150.

48 Ibid., 149. 
dilaksanakan setiap malam Jumat secara berjemaah. Ketiga, mujähadah shahrījah. Keempat, mengikuti mujähadah rubu' al-sanah yang dilaksanakan oleh DPC PSW kabupaten Jombang. Kelima, mujähadah shahrìah ini diadakan di daerah-daerah lain Jombang. Keenam, mengikuti mujähadah nisf al-sanah yang dilaksanakan oleh DPW PSW provinsi Jawa Timur. Ketujuh, mengikuti dan ikut menyukseskan mujähadah kubrā yang dilaksanakan oleh Dewan Pinpinan Pusat Penyiar Sholawat Wahidiyah yang bertempat di Pesantren Attahdzib, Kantor Pusat Pengamal Sholawat Wahidiyah. Kategorinya meliputi mujähadah pengamalan 40 hari, mujāhadah kecerdasan, keamanan, sukses usaha, dan lain-lain.

\section{Penutup}

Dimensi kehambaan merupakan salah satu doktrin terpenting dalam Islam berkaitan relasi Tuhan dengan manusia sebagai makhluknya. Terpenuhinya hak-hak Tuhan terhadap makhluknya tergantung pada konsistensi dan kesungguhan manusia untuk mengaksentuasikan dimensi kehambaan tersebut. Pada saat yang sama, dimensi kehambaan juga menjadi tolok ukur bagi manusia berkaitan dengan tingkat ketaatan atau sebaliknya, kedurhakaannya kepada Tuhan. Dimensi kehambaan mengandaikan premis bahwa manusia diciptakan hanya semata-mata untuk selalu taat menjalankan pengabdiannya sebagai hamba. Ketaatan dapat dilihat dari kesungguhannya dalam menyeleraskan keseluruhan perilakunya, terutama dalam konteks beragama dengan lima varian hukum taklifi yang sudah baku berdasarkan ketentuan fiqh, ushul fiqh, dan kaidah fiqh. Pelanggaran terhadap kelima varian hukum taklifi dengan cara mengkreasi hukum baru, salah satunya, sama halnya dengan menegasikan dimensi kehambaan yang seharusnya melekat dalam diri manusia.

Wahidiyah merupakan salah satu gerakan sufisme atau tasawuf kultural yang dengan mijähadah dan berlatih istighräq secara konsisten dan sungguh akan dapat mengantarkan pengamalnya mencapai fase orang yang lebur dalam tarikan ilahi (fäni al-majdbub). Pencapaian derajat ini ditandai oleh pengamal yang mendapat anugerah Tuhan sebagai mustaghriq fi al-ahadiyah, pelaku sufi yang telah tenggelam ke dalam tawhìd al-aḥadìah atau mencapai mukäshafah dan mushähadah alqalb secara sempurna.

Tidak ada batas waktu berakhirnya pengamal dalam mengarungi fase fäni al-majdhüb. Bagi mereka yang tidak serius dalam ber-mujähadah 
maupun berlatih istighräq bisa jadi tidak akan pernah mencapai derajat mustaghriq. Namun pengamal yang melakukan mujähadah dalam berbagai bentuknya dan berlatih secara konsisten, ia akan mencapai derajat mustaghriq. Rentang waktu bagi pengamal yang fänì al-majdhüb tidak dapat ditentukan, karena bersifat sangat personal. Seorang pengamal yang berhasil, bisa jadi hanya satu detik merasakan kefanaan dalam tarikan ilahi, namun tidak tertutup kemungkinan dalam waktu yang cukup lama.

Pengamal yang fänì al-majdhüb sama halnya dengan telah memasuki dunia kewalian. Dimensi kehambaan yang seharusnya melekat dalam dirinya lenyap dan sirna. Tidak ada lagi ikatan dengan ketentuanketentuan hukum taklifì untuk mengukuhkan eksistensinya sebagai hamba di hadapan Tuhannya. Dalam fase ini, berlaku hukum "serba boleh" untuk berkata dan berperilaku apapun. Dalam perspektif fäni al-majdhüb, kedudukan pengamal dalam fase ini berada di atas kenabian dan risalah (al-Qur'ān dan Hadīth). Ia melingkupi seluruh kenabian yang telah ada sepanjang sejarah umat manusia, sedangkan kenabian dan risalahnya terbatasi oleh zaman dan umat tertentu. Konsekuensinya, ia memiliki kebebasan untuk berbicara dan berbuat serba boleh, termasuk menciptakan sharīah baru pada saat berlangsungnya fase fāni al-majdhüb.

Doktrin ini semenjak awal juga telah ditransformasikan kepada peserta didik yang menempuh pendidikan di sekolah-sekolah formal yang dikelola oleh elit pengamal Wahidiyah, seperti di Rejo Agung Ngoro Jombang. Seluruh peserta didik pada jenjang pendidikan dasar dan menengah satuan MTs Ihsaniyat, SMPIT Ihsaniyat, MA Ihsaniyat, dan SMK Ihsaniyat wajib berpartisipasi aktif dalam serangkaian kegiatan mijähadah yang diselenggarakan oleh sekolah maupun pesantren. Keikutsertaan mereka dalam mujähadah, sama halnya memperkenalkan istighräq yang berpotensi pada pencapaian istighräq ahadiyah. Sebuah fase pendakian yang memperbolehkan pelakunya untuk menegasikan dimensi-dimensi kehambaan kepada Tuhannya.

\section{Daftar Rujukan}

'Ajībah, 'Abd Allah Aḥmad b. Mirräj al-Tashawwuf ilā Haqä’iq alTasanwwuf. Kairo: Dār al-Bayḍā', t.th.

'Ālim (al), Yūsuf Ḥāmid. al-Maqāsid al-Āmmah li al-Sharī'ah al-Islämīyah.

Riyad: Dār al-'Ālamīyah li al-Kitāb al-Islāmīi, 1994. 
'Āshūr, Muḥammad al-Ṭāhir b. Maqāsid al-Sharī'ah al-Islämīyah. Ardan: Dār al-Nafā'is, 2001.

'Umar, 'Umar b. Șāliḥ b. Maqāsid al-Sharīah 'ind al-Imām Tzz b. 'Abd alSalàm. Ardan: Dār al-Nafā'is, 2003.

Āmalī (al), Haydar. Asrār al-Sharīah wa Atwār al-Tariqah wa Anwār alHaqiqah. Libanon: Dār al-Mụhijah al-Bayḍā', 2012.

Bahreisy, Salim. Tarjamah Hikam li al-Syaikh Abmad Ibn Athäillah alSakandari. Surabaya: Penerbit Balai Buku Surabaya, 1980.

Hakīm (al), Su'ād. al-Mu'jam al-Süfìyah: al-Hikmah fì Hudūd al-Kalimah. Beirut: Dandarah li al-Ṭibā'ah wa al-Nashr, 1981.

Ḥasanī (al), Aḥmad b. Muḥammad b. 'Ajībah. İqāa al-Himam fì Sharḥ al-Hikeam. Kairo: Dār al-Ma'ārif, 1983.

Hosna, Rofiatul dan Arifin, Imron. "Principal Spiritual Leadership in Strengthening Character Education Through the Teachings of Sholawat Wabidiyah at Vocational High School Ihsanniat Jombang Indonesia", Advances in Social Science, Education and Humanities Research, Vol. 128, 2017.

Huda, Sokhi. Tasawnf Kultural: Fenomena Sholawat Wahidiyah. Yogyakarta: LKiS, 2008.

Ichwan, Moch. Nur. "The Local Politics of Orthodoxy: The Majelis

Ulama Indonesia in the Post-New Order Banten", Journal of Indonesian Islam, Vol. 6, No. 1, Juni 2012.

Maḥmūd, 'Àbd al-Halīm. al-Madrasah al-Shādhilīyah al-Hadìthah wa Imāmuha Abū al-Hasan al-Shādhilì. Kairo: Dār al-Kutub alHadithah, t.th.

Masyhudi, In'amuzzahidin. Wali Sufi Gila. Yogyakarta: Penerbit ArRuzz Press, 2003), 27.

PSW, DPP. Kuliah Wahidiyah. Jombang: Dewan Pimpinan Pusat Penyiar Sholawat Wahidiyah, 2005.

PSW, DPP. Penjelasan tentang Hal-bal yang Sering Dipermasalabkan dalam Wabidiyah. Jombang: Dewan Pimpinan Pusat Penyiar Sholawat Wahidiyah, t.th.

PSW, DPP. Tuntunan Mujahadah dan Acara-acara Wabidiyah. Jombang: Dewan Pengurus Pusat Penyiar Sholawat Wahidiyah, 2015.

Qushayrī (al), 'Abū al-Qāsim 'Abd al-Karīm b. Hawāzin. al-Risālah alQushayrìyah, terj. Khalil Manșūr. Beirut: Dār al-Kutub al-'Ilmīyah, 2001. 
Sha'rānī (al), 'Abd al-Wahāb. "Shatahāt al-Ṣufíyah al-Musammā bi alFatḥ fì Ta'wīl mā Ṣadara 'an al-Kamāl min al-Shațah", dalam Abū Yazīd al-Bustāinī, al-Majmū'ah al-Süfìyah al-Kämilah. Damaskus: Dār al-Madā li al-Nashr wa al-Tawzī‘ 2004.

Sha'rānī (al), 'Abd al-Wahāb. Irshäd al-Ṭälibin ilā al-Marätib al-Ulamä' alĀmilīn. Kairo: Dār al-Karāz li al-Nashr wa al-Tawzī', 2006.

Sha'rānī (al), 'Abd al-Wahāb. Latäî al-Minan wa al-Akhlāq fì Wujūb alTahadduth bi al-Ni'mah 'ala al-Ithāq al-Ma'rüf bi al-Mĩāin al-Kubrā. Damaskus: Dār al-Taqwā li al-Nashr wa al-Tawzī', 2004.

Sha'rānī (al), 'Abd al-Wahāb. Minhāj al-Wusūl ilā Maqāsid Tlm al-Ușūl. Kairo: Dār al-Fattāḥ li al-Dirāsah wa al-Nashr, 2013.

Sha'rānī (al), 'Abd al-Wahāb. Ṭabaqāt al-Kubrā al-Musammā Lawāị̀ alAnwār al-Qudsīyah fì Manāqib al-Ulamā' wa al-Süfiyah, Vol. 2. Kairo: Maktabah al-Thaqāfah li al-Dīnìyah, 2005.

Shofwan, Arif Muzayin. "Dakwah Sufistik KH. Abdoel Madjid Ma'roef Melalui Tarekat Wahidiyah", Jurnal Studi Masyarakat, Religi, dan Tradisi, Vol. 3, No. 1, Juni 2017.

Zahid, Moh. "Islam Wahidiyah, Ajaran dan Pengamalan Shalawât Wahidiyah dalam Mainstream Islam Masyarakat Madura", al-Ihkam: Jurnal Hukum dan Pranata Sosial, Vol. 7, No. 2, Desember 2012.

Zamhari, Arif. Rituals of Islamic Spirituality: a Study of Majlis Dhikr Groups in East Java. Canberra: The Australian National University, 2000.

Zuhaylī (al), Wahbah. al-Wajī̌ fì Usūul al-Fiqh. Beirut: Dār al-Fikr alMu'āṣir, 1999. 